\title{
Foreword
}

The globalization process constantly spawns new ideas, and researchers are generally willing to share and adapt them. It can be recalled that UNDP report no. I/1990 saw the basic objective of human development as the enlargement of the range of people's choices, which are not fixed forever. There have been many approaches to the study of human development. For instance, Classical Economics measures human development using the size of a country's GDP or per capita income. The Welfare Approach uses income and consumption. The Utilitarian Approach focuses on happiness, good and pleasure, while the Basic Needs Approach measures access to water, shelter, food and sanitation, among others. It is impressive that, just ten years later, Amartya Sen managed to pull all these ideas together into a single framework called the Capability Approach. This new concept of measuring human development focuses on freedom as development. Although nowadays widely known, the Capability Approach is still rarely used in population studies and policies, and this is especially true for Africa. This volume is therefore welcome, but in addition it is timely, and this for at least two reasons.

First, the philosophy and principles behind the present "ICPD beyond 20I4" process share the same red thread. The Framework of Action for the follow-up opens by stating that "development is the expansion of human opportunity and freedom"i, which corresponds exactly to the definition of Capabilities. The substance of the Capability Approach is at the heart of the three principles that underpin the ICPD Africa Regional Report just published":

- Right to development: the people of Africa have the right to develop in all spheres of life, including human rights and human development, and in peace and security;

- Empowering and Increasing the capacity of people to play a more strategic role in development; and

- Justice, equality and human dignity and rights for achieving inclusive and sustainable development.

Second, the use of data for analytical work to inform policy and programmes is at the center of national and international activities. In particular, Mali and Ghana, are both in the process of producing final results of the most recent Population and Housing Census. The expectations surrounding the awaited data attest to the latter's importance - for elections, the creation of district assemblies and resource allocations. In Mali, the recent instability has held back the dynamics of development; much remains to be done, in particular to restore the health and education systems, and this should be an opportunity to look for new paths. There is therefore an urgent need to encourage and enable national institutions and partners to generate, analyze and use population data to strengthen and monitor programs and development goals. The new methodology the focus on multiple reasons why people have varying access to resources and varying ability to use them - holds great promise for identifying local problems. The recognition that explaining limited wellbeing by the lack of resources is not a sufficient analysis of the development problems is a powerful one, and must be both extensively and intensively examined in order to understand the growing disparities and identify the best indicators to track inequalities in opportunities.

The papers that make up the present volume are the outcome of the project "Enhancing the Capabilities of the most vulnerable: a pilot project on inequalities in human development in Mali and Ghana", financially supported by the Swiss Network for International Studies and UNFPA Technical 
Division (New York). They have been discussed in two field workshops that took place in Sogakope, Ghana, in April 2012 and in Bamako, Mali, in December 2013, with the financial and technical support of the respective UNFPA country offices. During these workshops, scholars and professional staff of governmental and non-governmental organizations active in population issues had the opportunity to discuss thoroughly this conceptual framework and to gain a better understanding of it. The interest and expectations raised in both countries are evidence of the pertinence of the Capability Approach for local analysts and policy makers in population issues.

This volume thus provides a valuable reference regarding the main concepts of the framework and illustrations of its application.
The two countries, Ghana and Mali, where the analytical work was undertaken share some fundamental similarities while being different in many ways. The Capability analysis is brought to bear in the two situations. It provides clues for understanding the points of convergence and divergence, in other terms for highlighting new perspectives in comparative analysis that focus on differences in opportunities rather than just comparing achieved levels. Finally, the Capability analysis is a tool to build bridges between academia and development practitioners. The resulting collaboration will not only yield practical results for making informed decisions, but could also be the springboard for a sustainable partnership. This should be one of the objectives of the follow up of this project.

The Ghana and Mali Teams ${ }^{\text {iii }}$ 


\section{Avant Propos}

Le processus de globalisation a fait jaillir un flux de nouvelles idées que les chercheurs partagent et adaptent. Rappelons que le rapport I/1990 du PNUD considérait l'objectif fondamental de développement humain comme l'élargissement de l'éventail de choix des gens, considéré comme non fixés une fois pour toute. L'étude du développement humain a été marquée par plusieurs approches. Par exemple, l'économie classique le mesure par le Produit national brut ou le produit par habitant. L'approche centrée sur le bien-être (Welfare) se réfère au revenu et aux indices de consommation, alors que l'approche utilitariste se centre sur le bonheur, le bien et le plaisir, et celle des besoins de base mesure l'accès notamment à l'eau, au logement, à la nourriture et à l'assainissement. II est impressionnant de constater que seulement dix ans plus tard, Amartya Sen réussissait à rassembler ces diverses idées dans un cadre unique appelé l'Approche des Capabilités. Ce nouveau concept pour mesurer le développement humain met l'accent sur le développement conçu comme une liberté. Bien que, aujourd'hui, largement connue, l'Approche des Capabilités n'est que peu utilisée dans les études et politiques relatives aux questions de population, ce qui est particulièrement vrai en Afrique. Ce volume est donc spécialement bienvenu et, de plus, il arrive au bon moment au moins pour deux raisons.

D'une part, la philosophie et les principes qui sous-tendent le processus actuel 'CIPD audelà de 2014' partagent le même fil rouge. Le cadre d'action pour le suivi s'ouvre en déclarant que «le développement représente l'expansion d'opportunité et de liberté humaines»', ce qui correspond exactement à la définition des Capabilités. Les fondements de l'Approche des Capabilités sont au cœur des trois principes qui fondent le rapport régional africain du suivi de la CIPD qui vient de paraître ${ }^{2}$ :

- Droit au développement: les peuples d'Afrique ont le droit au développement dans toutes les domaines de l'existence, y compris en matière de droits et développement humains, et à la paix et à la sécurité;

- 'Empowering' et renforcement des capacités des gens à jouer un rôle plus stratégique dans le développement; et

- Justice, égalité et dignité humaine, et droits à atteindre un état de développement complet et durable.

D'autre part, l'utilisation des données pour des analyses destinées à informer les politiques et programmes est au centre des activités aux niveaux national et international. En particulier, le Mali et le Ghana, sont tous deux en train de produire les résultats finaux des derniers recensements de la population et de l'habitat. Les attentes entourant les données attendues attestent de l'importance qui leur est attribuée pour les élections, la création d'assemblées de district et d'allocations de ressources. Au Mali, les récents troubles ont freiné la dynamique de développement ; il y a encore beaucoup à faire, en particulier, pour rétablir le fonctionnement du système de santé et d'éducation et cela devrait être aussi une opportunité pour chercher de nouvelles solutions. II y a donc un besoin urgent de soutenir les institutions nationales et les partenaires pour les rendre aptes à produire, analyser et utiliser les données sur les questions de population pour renforcer et évaluer le fonctionnement des programmes et les objectifs de développement. Cette nouvelle méthodologue - qui met l'accent sur les raisons multiples pour lesquelles les gens ont un accès variable aux ressources et une capacité inégale à les utiliser - est prometteuse pour identifier les problèmes locaux. La reconnaissance que, expliquer le manque de bien-être par les carences de ressources, ne constitue pas une analyse suffisante des problèmes de développement, est importante 
et demande à être examinée de façon approfondie pour comprendre les inégalités croissantes et sélectionner les meilleurs indicateurs pour identifier les inégalités en termes d'opportunités.

Les articles qui constituent le présent volume sont le résultat du projet « Renforcer les Capabilités des plus vulnérables: un projet pilote sur les inégalités de développement humain au Mali et au Ghana ". financé par le SNIS (Swiss Network for International Studies) et la Division technique du FNUAP ( $\mathrm{New}$ York). Ces résultats ont été discutés lors de deux ateliers qui ont eu lieu à Sogakope au Ghana en avril 2012 et à Bamako (Mali) en décembre 2013 avec l'appui technique et financier des bureaux pays respectifs du FNUAP. Au cours de ces ateliers, des chercheurs et des collaborateurs d'organisations gouvernementales et non-gouvernementales actives dans les questions de population ont pu discuter de façon approfondie de ce cadre conceptuel et ainsi en avoir une meilleure compréhension. L'intérêt suscité et les attentes exprimées dans les deux pays témoignent de la pertinence de l'Approche des Capabilités pour les analystes et décideurs locaux dans le domaine de la population.

$\mathrm{Ce}$ volume fournit donc une référence précieuse sur les principaux concepts de ce cadre et des illustrations de son application. Les analyses ont été réalisées au Ghana et au Mali, deux pays qui partagent des similarités fondamentales mais diffèrent à de nombreux égards. L'analyse des Capabilités est employée dans l'examen des deux situations. Elle fournit des pistes pour comprendre les convergences et divergences, en d'autres termes proposer une nouvelle perspective de l'analyse comparative qui mette l'accent sur les différences d'opportunités plutôt que simplement la comparaison des niveaux atteints. Finalement, l'analyse des Capabilités est un outil pour construire des ponts entre le monde académique et les praticiens du développement. Une telle collaboration devrait non seulement permettre des prises de décisions bien informées, mais aussi de construire un partenariat durable. C'est un des objectifs que devraient avoir les suites données au projet.

Les équipes du Mali et du Ghana 


\section{ACKNOWLEDGEMENTS}

We would like to thank all the Institutions that have contributed to make this project a reality: The project has been financed by the Swiss Network for International Studies (SNIS) and received an additional grant from the UNFPA Technical Division, New York, for a complementary analysis on family plans ("Shaping the Family"). It has also benefitted from the support of the two national UNFPA offices in Bamako and Accra for the organization of national workshops of diffusion of the outcomes; the UNFPA Bamako office has also financed the printed copies of the present volume.

The implementation of this project also owes much to the full support of the Faculties of the five Universities involved as regard infrastructure, time of senior researchers and organization of meetings : Dpt of Public Health and specialties, Faculty of Medecine and Pharmacy (FMPOS), University of Bamako; Dpt of Geography and Regional Institute for Population Studies, University of Ghana at Legon; Dpt of Political and Social Science, University of Pavia and the Human Development, Capability and Poverty International Research Centre, Institute for Advanced Study, Pavia (Italy); Harvard School of Public Health and Harvard Center for Population and Development Studies. The Institute of Demographic and Life course studies (I-DEMO) and the respective services of the Faculty of economic and social sciences of the University of Geneva, have been in charge of the management and coordination of the project.

The authors are especially grateful to the colleagues who have accepted to function as referees and for their very valuable and constructive suggestions that have greatly contributed to the quality of the papers :
Kofi AWUSABE-ASARE, Professor in Population

Studies at the University of Cape Coast, Ghana;

Claudine BURTON-JEANGROS, Professeure, Dpt de sociologie, Université de Genève ;

Valérie DELAUNAY, Institut pour la recherche et le développement (IRD), Dakar ;

Hélène DELISLE, Professeur, Faculté de

Médecine, Université de Montréal ;

Véronique FILIPPI, Lecturer, London School of

Hygiene and Tropical Medecine ;

Michael GRIMM, Professor of Development

Economics, University of Passau (Germany) ; Jean-François KOBIANE, Professeur Institut Supérieur des Sciences de la Population, Université de Ouagadougou ;

Sophie LECOEUR-LALLEMANT, Institut National d'Etudes Démographique (INED), Paris ;

Thérèse $\mathrm{LOCOH}$, Institut National d'Etudes Démographique (INED), Paris ;

Kevin LOMPO, Institut pour la recherche et le développement (IRD), UMR Paris-Nord et Professeur Université de Ouagadougou ;

Gora M'BODJ, Professeur Département de sociologie, Université de St Louis, Senegal ;

Marc PILON, Institut pour la recherche et le développement (IRD), UMR CEPED Paris Descartes-INED ;

Clémentine ROSSIER, Professeur Institut d'études démographiques et du parcours de vie, Université de Genève et Institut National d'Etudes Démographique (INED), Paris ;

Sridhar VENKATAPURAM Lecturer King's College London ;

Kokou VIGNIKIN, Professeur Unité de Recherche Démographique (URD), Université de Lomé (Togo).

Former versions of some of the papers have been presented at scientific conferences (UAPS Ouagadougou 20II, AIDELF Ougadougou 2012, Chaire Quetelet 2012, IUSSP Busan 20I3) and have benefitted from pertinent comments especially of the presidents and 
discussants of the sessions. We also thank AIDELF and IUSSP who allow a further publication of the papers published on their website.

' Framework of action for the follow-up to the Programme of Action of the International Conference on Population and Development beyond 2014, revised July 2014:

http://icpdbeyond2014.org/uploads/browser/files/global_revie w_report_for_uploading_2.pdf

ii

http://issuu.com/shiralevine/docs/icpd_regional_report_versio n_5_afri/0

iii Département de santé publique, Faculté Médecine, Université du Mali, Bamako. Department of Geography and Regional Institute Population Studies, University of Ghana at Legon. And the UNFPA field offices in Mali and Ghana. 